\title{
T-cassette Ligation: A Method for Direct Sequencing and Cloning of PCR-amplified DNA Fragments
}

\author{
Hiroyuki Iwahana, Katsuhiko Yoshimoto, Toshiyuki Tsujisawa, and Mitsuo Itakura \\ Otsuka Department of Clinical and Molecular Nutrition, School of Medicine, The University of Tokushima, \\ Tokushima 770, Japan
}

\begin{abstract}
We describe a method to ligate a PCR-amplified DNA fragment with T-protruding cassettes, which have multiple sites for endonuclease, promoter sequences of $\mathrm{T} 3$ and $\mathrm{T7}$, and annealing sites for the universal M13 forward and reverse primers. This method, which we named T-cassette ligation, substantially facilitated direct sequencing and subcloning of PCR products. Two T-cassettes with a protruding $T$ at their $3^{\prime}$ ends were obtained by annealing adaptor oligomers to Xbal- or Xhol-digested pBluescript. A DNA fragment amplified by the first PCR was ligated separately to one of the two T-cassettes. The second PCR was performed using a primer complementary to one of the two T-cassettes and one of the two primers used for the first PCR to amplify the ligation product in low abundance. The resultant two DNA fragments had the T3 and T7 promoter, and an annealing site for the universal M13 forward and reverse primer, respectively. These DNA fragments were applicable to direct sequencing. For the purpose of subcloning, the third PCR was carried out with two primers each complementary to each of two T-cassettes and two PCR-amplified DNAs by the second PCR, as templates. The PCR product of the third PCR had multiple sites of the pBluescript polycloning site at both ends, facilitating its subcloning into pBluescript.
\end{abstract}

CR selectively amplifies a discrete DNA segment from genomic or complementary DNA. However, subcloning of an amplified DNA fragment into a plasmid is often troublesome and time-consuming. Because Taq DNA polymerase used for PCR has the template-independent terminal transferase activity, (1) ligation of a PCR product to a blunt-ended vector is not effective. ${ }^{(2)}$ To overcome this problem, blunt-ending of PCR products with the Klenow fragment of DNA polymerase $\mathrm{I}^{(2)}$ or creation of sticky ends by introducing restriction endonuclease recognition sites at the $5^{\prime}$ ends of the two amplification primers, is often used. ${ }^{(3,4)}$ In addition so-called $T$ vectors were devised, ${ }^{(5-7)}$ because the Taq DNA polymerase has strong preference for dATP in the template-independent terminal transferase activity. (1) Two different ligase-independent methods to clone amplified DNA fragments with long annealing sequences and unligated gaps were reported. ${ }^{(8-10)}$ The trimming methods for making specific sticky ends were reported, in which both a PCR product and a cloning vector were trimmed using T4 DNA polymerase and Klenow fragment. ${ }^{(4,11,12)}$

Here, we developed a highly efficient T-cassette ligation method by incorporating a PCR amplification step after ligation. T-cassettes with a protruding $T$ at the $3^{\prime}$ end have multiple sites for endonuclease recognition, the $\mathrm{T} 3$ and $\mathrm{T} 7$ promoter sequences and annealing sites for the universal M13 forward and reverse primer. Because of these sequences, both direct sequencing and subcloning of a PCR-amplified DNA fragment are greatly facilitated.

\section{MATERIALS AND METHODS Genomic DNA Isolation}

High molecular weight DNA was prepared from peripheral white blood cells from a healthy volunteer and a lung cancer cell line of Lu65 by the standard method. ${ }^{(13)}$ Lu65, which was provided by S. Hirohashi (National Cancer Center Research Institute, Tokyo, Japan), has a point mutation of the K-ras gene at codon 12 [GGT(Gly) $\rightarrow$ TGT(Cys)]. ${ }^{(14)}$

\section{Synthesis of Oligomers}

Two adaptor oligomers oRB729(XbaI) and oRB730(XhoI) to construct two T-cassettes, pBluescript annealing primers of oRB14, oRB15, oRB399, and oRB401, and primers of FIM-1 and FIM-2 to amplify the K-ras gene are listed in Table 1 . These oligomers were synthesized by ABI 392 DNA/RNA synthesizer (Applied Biosystems, Foster City, CA).

\section{Construction of Two Annealing T-cassettes}

T-cassettes with a protruding $\mathrm{T}$ at their $3^{\prime}$ ends were constructed by the sequential steps shown in Figure 1. pBluescript II $\mathrm{SK}+(0.5 \mu \mathrm{g}$; Stratagene, La Jolla, CA $)$ was digested with 5 units of $\mathrm{XbaI}$ [Boehringer Mannheim GmbH (BMG), Mannheim, Germany] or Xhol (BMG) in a total volume of $20 \mu$ l. Five microliters each of oRB729(XbaI) (10 pmoles/ $\mu \mathrm{l})$ and oRB730(Xhol) (10 pmoles/ $\mu$ l) was added to the XbaI- and XhoI-digested pBluescript, respectively. The molar ratio of an adaptor oligomer to a linearized plasmid was 200:1. The mixtures were heated at 
TABLE 1 Sequences of Oligomers Used for T-cassette Construction and PCR

\begin{tabular}{lll}
\hline Names & Sequences & Notes \\
\hline oRB729(XbaI) & 5'-AT CCACTAGTT CT A GT -3' & adaptor for Xbal-digested pBluescript \\
oRB730(Xhol) & 5'-T ACCGT CGACCTCGAT-3' & adaptor for Xhol-digested pBluescript \\
oRB15 & 5'-GT TGT AAAACGACGGCCAGT -3' & forward primer complementary to pBluescript \\
oRB399 & 5'-CGAT T AAGT TGGGT AACGCC-3' & forward primer complementary to pBluescript \\
oRB14 & 5'-ACAGGAAACAGCT T GACCA-3' & reverse primer complementary to pBluescript \\
oRB401 & 5'-T TAT GCT T CCGGCT CGTAT G-3' & reverse primer complementary to pBluescript \\
FIM-1 & 5'-GGCCT GCT GAAAAT GACT GA-3' & forward primer to amplify the K-ras gene \\
FIM-2 & 5'-GT CCT GCACCAGT AAT AT GC-3' & reverse primer to amplify the K-ras gene \\
\hline
\end{tabular}

$95^{\circ} \mathrm{C}$ for 3 min and annealed by cooling to room temperature. We named the oRB729(XbaI) annealing cassette cBT1 and the oRB730(Xhol) annealing cassette CBT2.

\section{PCR amplification and Ligation with Two Annealing T-cassettes}

The flowchart, as shown in Figure 2, includes the first PCR, ligation with one of the two annealing T-cassettes, the second and third PCRs. To amplify a 162-bp DNA fragment of the $\mathrm{K}$-ras gene in the first PCR, mixture was made in $10 \mu \mathrm{l}$ containing $1 \mu \mathrm{M}$ each of FIM- 1 and FIM-2 primers, $200 \mu \mathrm{M}$ of dATP, dCTP, dGTP, and dTTP, $100 \mathrm{ng}$ of human genomic DNA as a template, and $0.025 \mathrm{U} / \mu \mathrm{l}$ of Taq DNA polymerase (Kurabo, Osaka, Japan) in $10 \mathrm{~mm}$ Tris- $\mathrm{HCl}\left(\mathrm{pH} 9.0\right.$ at $\left.25^{\circ} \mathrm{C}\right)$, containing $50 \mathrm{~mm} \mathrm{KCl}, 1.5 \mathrm{~mm} \mathrm{MgCl}_{2}$, and
$0.1 \%$ Triton $\mathrm{X}-100$. Thirty reaction cycles at 95,55 , and $72^{\circ} \mathrm{C}$ for 1,1 , and $2 \mathrm{~min}$, respectively, proceeded in a Program Temp Control System PC-700 (Astec, Fukuoka, Japan). After the last cycle, polymerization at $72^{\circ} \mathrm{C}$ was extended to 10 min to complete the elongation reaction. After PCR amplification, electrophoresis was performed on an $8 \%$ polyacrylamide gel. A 162-bp band was cut out and DNA was extracted by the "crush

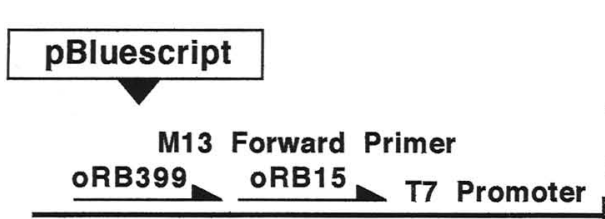

Polycloning Site of pBluescript II SK+
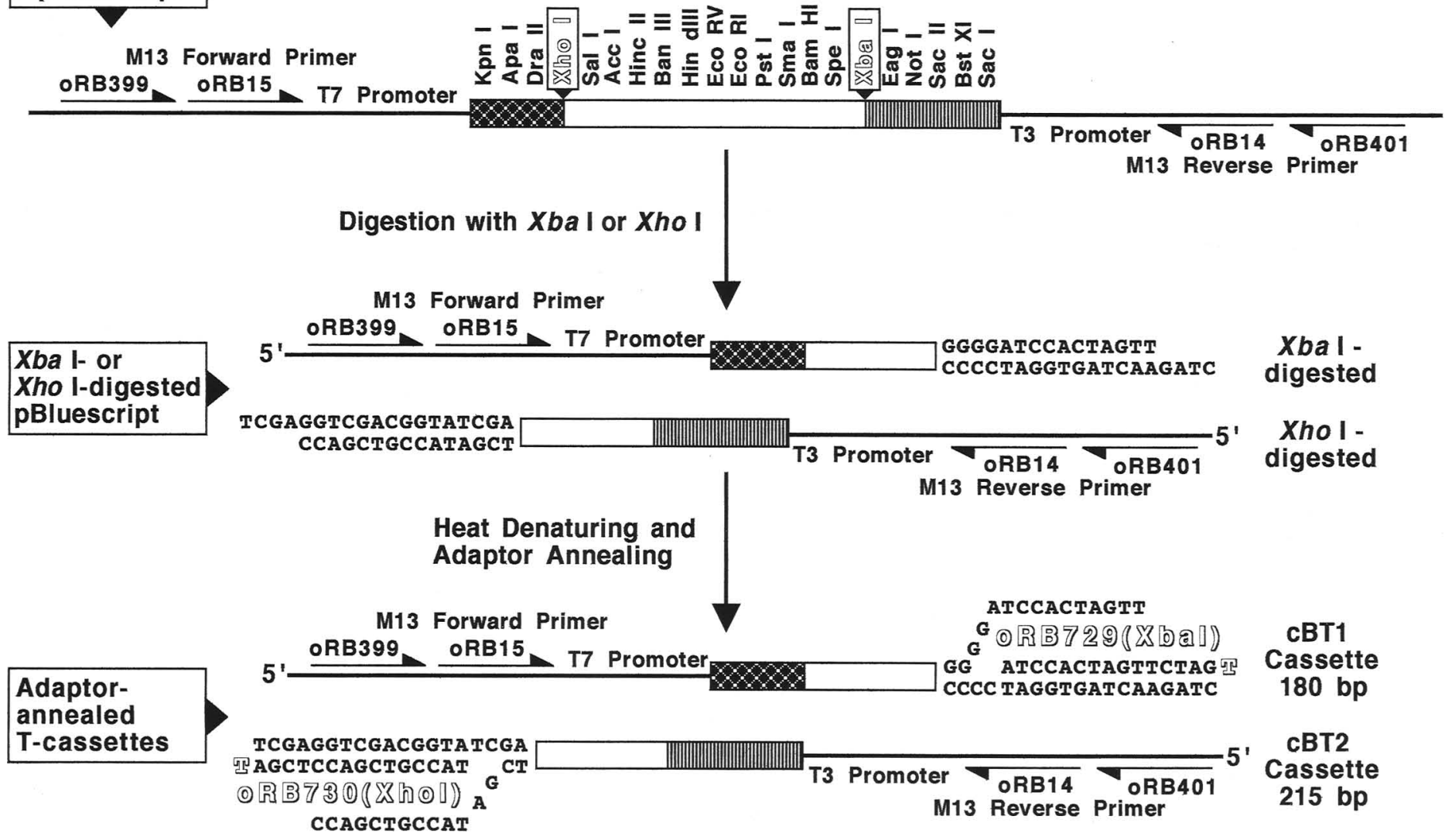

FIGURE 1 Schematic presentation of the construction of T-cassettes. A plasmid of pBluescript II SK + was digested with Xbal or Xhol. The adaptor oligomer of oRB729(XbaI) or oRB730(XhoI) was added to the Xbal-or Xhol-digested pBluescript, respectively. The mixtures were heat-denatured and annealed by cooling to room temperature. We named oRB729(XbaI) annealing cassette as $\mathrm{CBT} 1$, and oRB730(XhoI) annealing cassette as $\mathrm{cBT} 2$. 


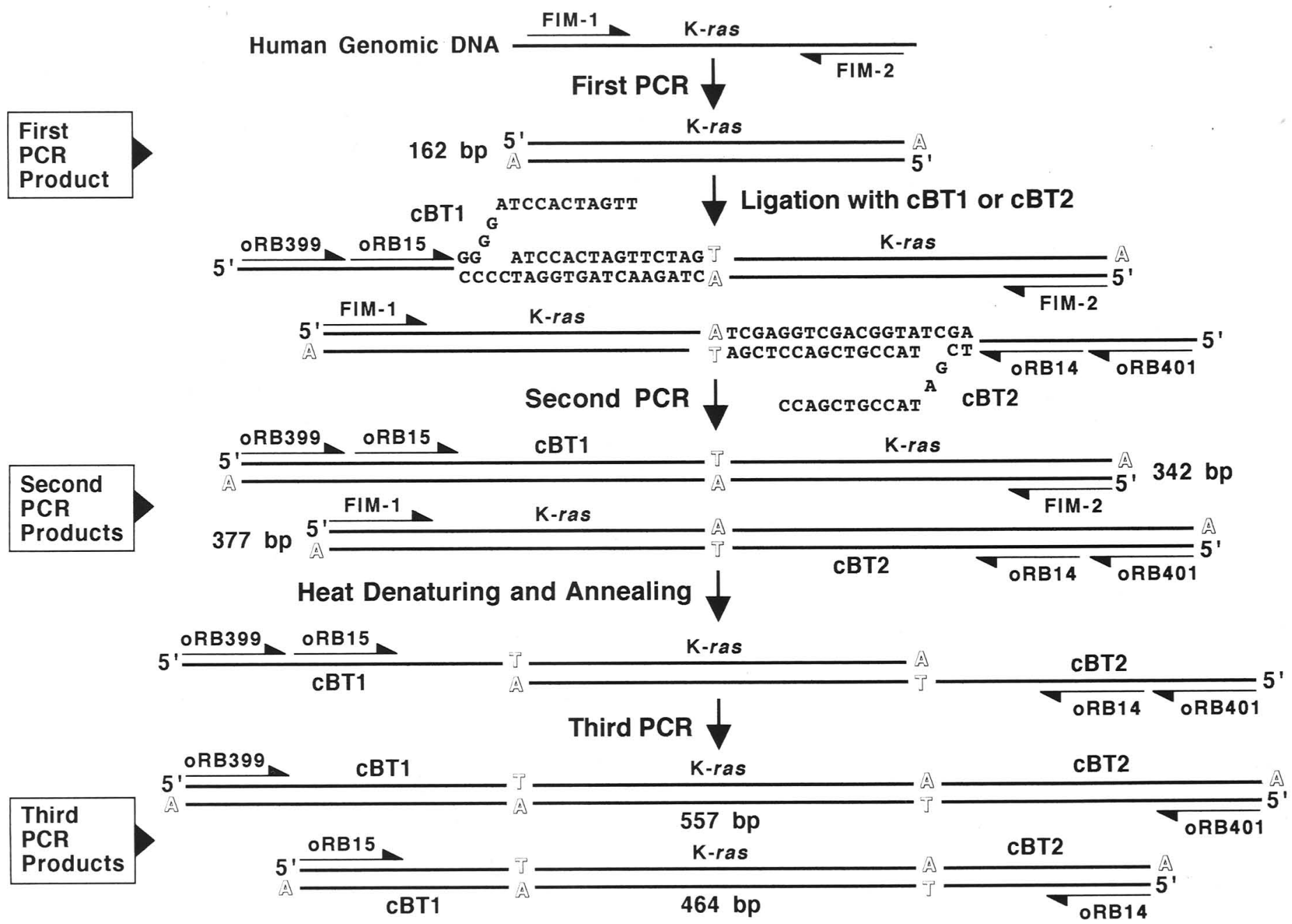

FIGURE 2 PCR amplification and ligation with two T-cassettes. The first PCR was performed with a pair of FIM-1 and FIM-2 primers using a genomic DNA as a template and a 162-bp DNA fragment of the K-ras gene was amplified. The T-cassettes of cBT1 or cBT2 were ligated to the amplified K-ras gene. The second PCR was performed using one of primers complementary to T-cassettes (oRB399 or oRB401) and one of the primers complementary to the K-ras gene (FIM-1 and FIM-2). The K-ras gene ligated to CBT1 or CBT2 was used as a template. The third PCR was carried out using a pair of primers of oRB399-oRB401 or oRB14-oRB15 complementary to T-cassettes. The second PCR products, which had cBT1 or CBT2 at the $5^{\prime}$ end, were mixed and used as templates.

and soak" method ${ }^{(15)}$ with slight modification. Briefly, gel slice was crushed and suspended in about 2 volumes of elution buffer containing $0.5 \mathrm{M}$ ammonium acetate, $10 \mathrm{~mm}$ magnesium acetate, 1 mM EDTA (pH 8.0), and 0.1\% SDS. The crushed gel was incubated at $37^{\circ} \mathrm{C}$ for several hours with shaking and centrifuged at $15,000 \mathrm{rpm}$ for $2 \mathrm{~min}$ at $4^{\circ} \mathrm{C}$. The supernatant was transferred to a fresh microcentrifuge tube. The pellet was resuspended in about 0.5 volume of elution buffer and centrifuged again. Two supernatants were combined and centrifuged. The supernatant was ethanol-precipitated twice. The recovered DNA was dissolved in $10 \mu \mathrm{l}$ of deionized and autoclaved water (DA water). From 3.3 to $3.7 \mathrm{ng}$ of the amplified and ex- tracted K-ras gene in $0.5 \mu \mathrm{l}$ and $20 \mathrm{ng}$ of cBT1 or cBT2 T-cassette in $0.5 \mu$ l were ligated using a DNA ligation kit (Takara, Kyoto, Japan) in a total volume of $6 \mu \mathrm{l}$ at $16^{\circ} \mathrm{C}$ for $1 \mathrm{hr}$. The molar ratios of a PCR product to a $\mathrm{T}$-cassette used in the initial ligation were 3.0-3.4:1.

The second PCR was performed using primers (oRB399 or oRB401) complementary to T-cassettes and one of the primers (FIM-1 and FIM-2) complementary to the K-ras gene, in a total volume of $50 \mu \mathrm{l}$. One microliter of the K-ras gene ligated to cBT1 or CBT2 was used as a template. Forty-five microliters of the second PCR product was electrophoresed on an $8 \%$ polyacrylamide gel and DNA was isolated by the slightly modified crush and soak method. The remaining 5 $\mu$ l was diluted 10 times with DA water and used as a template for the third PCR.

The third PCR was carried out using a pair of primers (oRB399-oRB401 or oRB14-oRB15) complementary to T-cassettes in a total volume of $50 \mu \mathrm{l}$. The second PCR products, which had cBT1 or CBT2 at the $5^{\prime}$ end, were mixed and used as templates. The amplified DNA fragment was electrophoresed and extracted as described above. The resultant DNA fragment was digested with NotI (BMG) and XhoI (BMG) and cloned into pBluescript.

\section{Endonuclease Digestion}

Five microliters of the second or third PCR products was digested with 5-10 

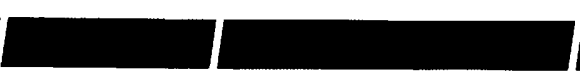

units of KpnI (BMG), Xhol (BMG), HindIII [New England Biolabs, Inc. (NEB), Beverly, MA], EcoRI (BMG), BamHI (NEB), Xbal (BMG), NotI (BMG), or SacI (NEB) in a buffer recommended by a manufacturer in a total volume of $20 \mu \mathrm{l}$. Electrophoresis was performed on an $8 \%$ polyacrylamide gel, and bands were visualized with ethidium bromide staining and UV trans-illumination.

\section{Nucleotide Sequencing}

Nucleotide sequence was determined using the Taq Dye Primer Cycle Sequencing Core Kit (401112) in the ABI 373A sequencer. The DNA fragment, which was amplified by the second PCR and extracted by the slightly modified crush and soak method, was used as a template for direct DNA sequencing. The DNA fragment, which was amplified in the third PCR and cloned into pBluescript, was also used as a template.

\section{RESULTS}

As shown in Figure 1, T-cassettes of CBT1 or $\mathrm{CBT} 2$ with a single protruding $\mathrm{T}$ were constructed by digesting pBluescript with $X b a I$ or $X h o I$, heat-denaturing, and annealing with the adaptor oligomer oRB729(XbaI) or oRB730(Xhol).

As shown in lane 2 of Figure 3, a 162bp DNA fragment of the K-ras gene containing codon 12 was amplified by PCR using a pair of primers of FIM- 1 and FIM2 . The 162-bp band was cut out from the gel and extracted. The amplified K-ras gene was ligated to the T-cassette of $\mathrm{CBT} 1$ or CBT2 and used as a template for the second PCR. The second PCR was performed using a pair of primers of oRB399-FIM-2 or oRB401-FIM-1. A 342bp DNA fragment, which was amplified with oRB399-FIM-2 (Fig. 3, lane 3), contained the $\mathrm{T} 7$ promoter sequence, the annealing site for universal M13 forward primer, and multiple endonuclease recognition sites of KpnI, ApaI, DraII, XhoI, SalI, AccI, HincII, BanIII, HindIII, EcoRV, EcoRI, PstI, SmaI, BamHI, and SpeI. The DNA fragment was clearly digested, as expected, with BamHI, EcoRI, XhoI, or KpnI (Fig. 3, lanes 4-7). A 377-bp DNA fragment, which was amplified with oRB401-FIM-1 (Fig. 3, lane 8), contained the T3 promoter sequence, the annealing site for universal M13 reverse primer, and multiple endonuclease recognition sites of SacI, BstXI, SacII, NotI, EagI, XbaI,

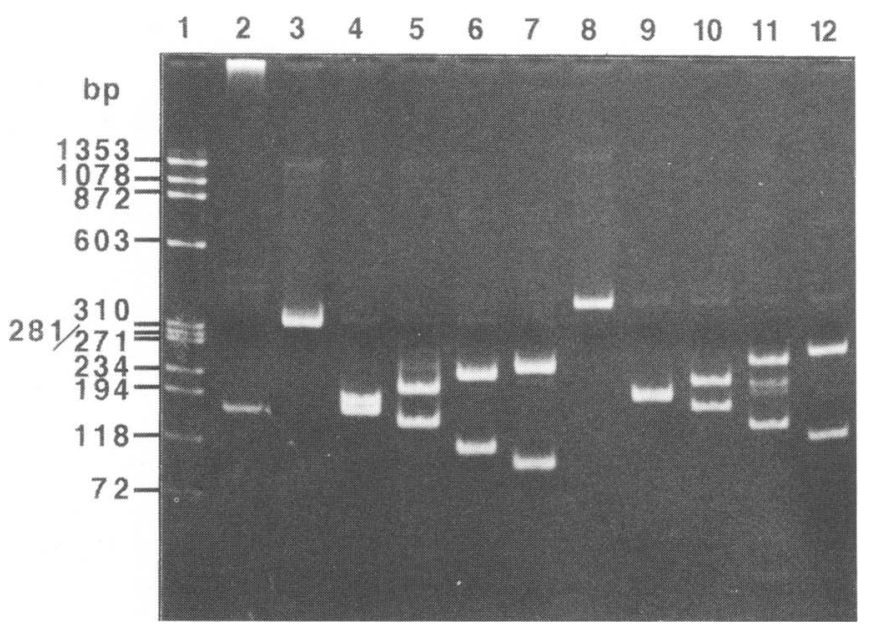

FIGURE 3 A gel image of the first and second PCR products. The first and second PCR products were digested with various endonucleases, electrophoresed on an $8 \%$ polyacrylamide gel, and visualized with ethidium bromide staining and UV trans-illumination. (Lane 1) DNA size markers of HaellI-digested $\phi \times 174$; (lane 2) a 162-bp DNA fragment of the K-ras gene amplified by the first PCR; (lane 3) a 342- bp DNA fragment amplified by the second PCR with oRB399-FIM-2; (lanes 4-7) the 342 bp DNA fragment was digested with BamHI, EcoRI, XhoI, or KpnI, respectively; (lane 8) a 377-bp DNA fragment amplified by the second PCR with oRB401-FIM-1; (lanes 9-12) the 377-bp DNA fragment was digested with HindIII, PstI, NotI, or Sacl, respectively.
SpeI, BamHI, SmaI, Pstl, EcoRI, EcoRV, HindIII, BanIII, HinclI, AccI, and Sall. The DNA fragment was clearly digested, as expected, with HindIII, PstI, NotI, or SacI (Fig. 3, lanes 9-12).

The DNA fragment amplified with oRB399-FIM-2 and the DNA fragment amplified with oRB401-FIM-1 were diluted 10 times with DA water and used as templates for the third PCR. The third PCR was performed using a pair of primers of oRB399-oRB401 or oRB14-oRB15. DNA fragments of 557 and 464 bp were amplified with oRB399-oRB401 and

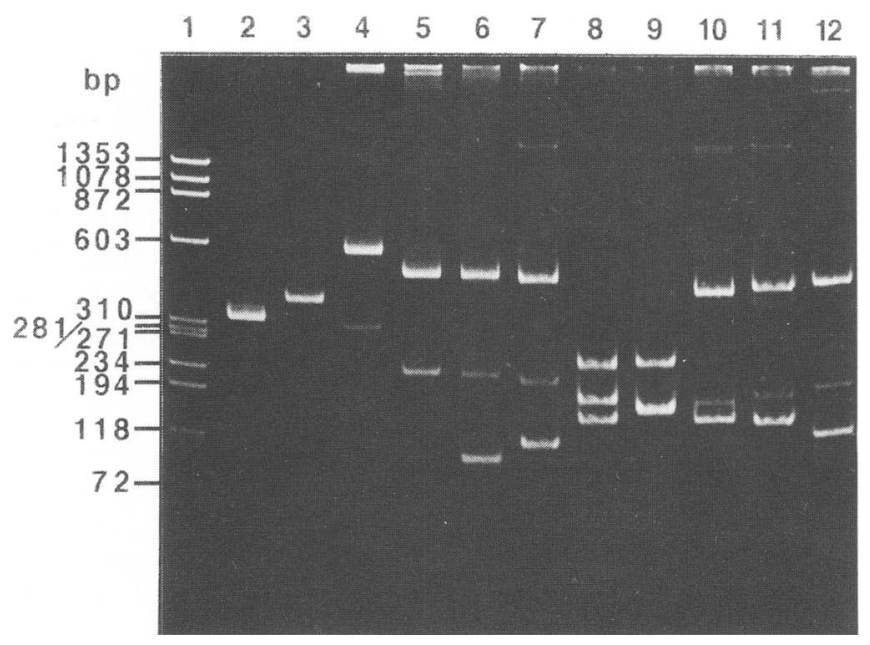

FIGURE 4 A gel image of the second and third PCR products. The second and third PCR products. which were digested with various endonucleases, were electrophoresed on an $8 \%$ polyacrylamide gel, and visualized with ethidium bromide staining and UV trums-illumination. (Lane $1, \mathrm{D}) \mathrm{A}$ - siz markers of HaellI-digested $\phi \times 174$; (lane 2) a 342-bp DNA fragment amplified by the second I' $R$ with oRB399-FIM-2; (lane 3) a 377-bp DNA fragment amplified by the second P' $C$ with oRB+111FIM-1; (lane 4) a 557-bp D.NA fragment amplified by the third PCR with oRB399-oRB401; 1lane 5) a 464-bp DNA fragment amplified in the third PCR with oRB 14-oRB 1.5; (lanes 6-12) the $5.57-1)$ ) DNA fragment was digested with KpnI, Xhol, EcoRI, BamHI, Xbal, Notl, or Sacl, respectivels 
oRB14-oRB15, respectively (Fig. 4, lanes 4 and 5). They had a single site for $K p n I$, Apal, DraII, Xhol, XbaI, EagI, NotI, SacII, BstXI, and SacI and two sites for SalI, AccI, HincII, BanIII, HindIII, EcoRV, EcoRI, PstI, SmaI, BamHI, and SpeI. Lanes 6-12 of Figure 4 show that the DNA fragment amplified with oRB399-oRB401 could be cut with KpnI, XhoI, EcoRI, BamHI, XbaI, NotI, and SacI, respectively.

The second PCR products, which were amplified with oRB399-FIM-2 or oRB401-FIM-1 using genomic DNA isolated from peripheral white blood cells of a normal control or a human lung cancer cell line of Lu65, were subjected to direct DNA sequencing. As reported previously, ${ }^{(14)}$ Lu65 was shown to have a point mutation of the K-ras gene at codon 12 [GGT(Gly) $\rightarrow$ TGT(Cys)] (Fig. 5).

The third PCR products, which were amplified with oRB399-oRB401 or oRB14-ORB15, were extracted from polyacrylamide gels and double-digested with NotI and XhoI. These DNA fragments were easily cloned into the pBluescript double-digested with NotI and
XhoI. Their nucleotide sequences were identical with that of the second PCR products (data not shown), which confirmed that the K-ras gene was cloned successfully.

\section{DISCUSSION}

Because Taq DNA polymerase has an activity of template-independent terminal transferase, a DNA fragment amplified with the polymerase has a single nucleotide at the $3^{\prime}$ end. ${ }^{(1)}$ The added nucleotide is almost exclusively an A because of the strong preference of the polymerase for dATP. (1) Taking this character into consideration, so-called $\mathrm{T}$-vectors with a protruding $T$ at the 3 ' end of the cloning site, were devised. ${ }^{(5-7)}$ We used T-vectors, which are commercially available as a cloning kit (TA cloning kit of Invitrogen, San Diego, CA), but subcloning by this method was not effective in our hands probably because of low efficiency of ligation.

The principle of a $\mathrm{T}$-cassette ligation method, as outlined in Figures 1 and 2, includes the PCR amplification of the
T-cassette ligated product in low abundance. We synthesized adaptor oligomers oRB729(Xbal) and oRB730(Xhol), which were annealed to the XbaI- or XhoI-digested pBluescript to construct T-cassettes of CBT1 or cBT2, respectively, with a single protruding $\mathrm{T}$ at the $3^{\prime}$ end. A PCR amplified DNA fragment, which had a protruding $A$ at the $3^{\prime}$ end, was ligated to $\mathrm{CBT} 1$ or $\mathrm{CBT} 2$, independently. In the initial ligation, a $T$-cassette would be ligated to both ends of the first PCR product. The second PCR was performed using a primer complementary to pBluescript and one of the primers used for the first PCR. Therefore, the second PCR amplified a DNA fragment that was ligated to a T-cassette and it uses one of the two T-cassettes ligated at both ends of DNA fragment for PCR amplification. The resultant PCR product of the second PCR had either the T3 or T7 promoter sequence, the annealing site for universal M13 forward or reverse primer, and those multiple endonuclease recognition sites that are present in the pBluescript polycloning site. These PCR products could be used as a template for

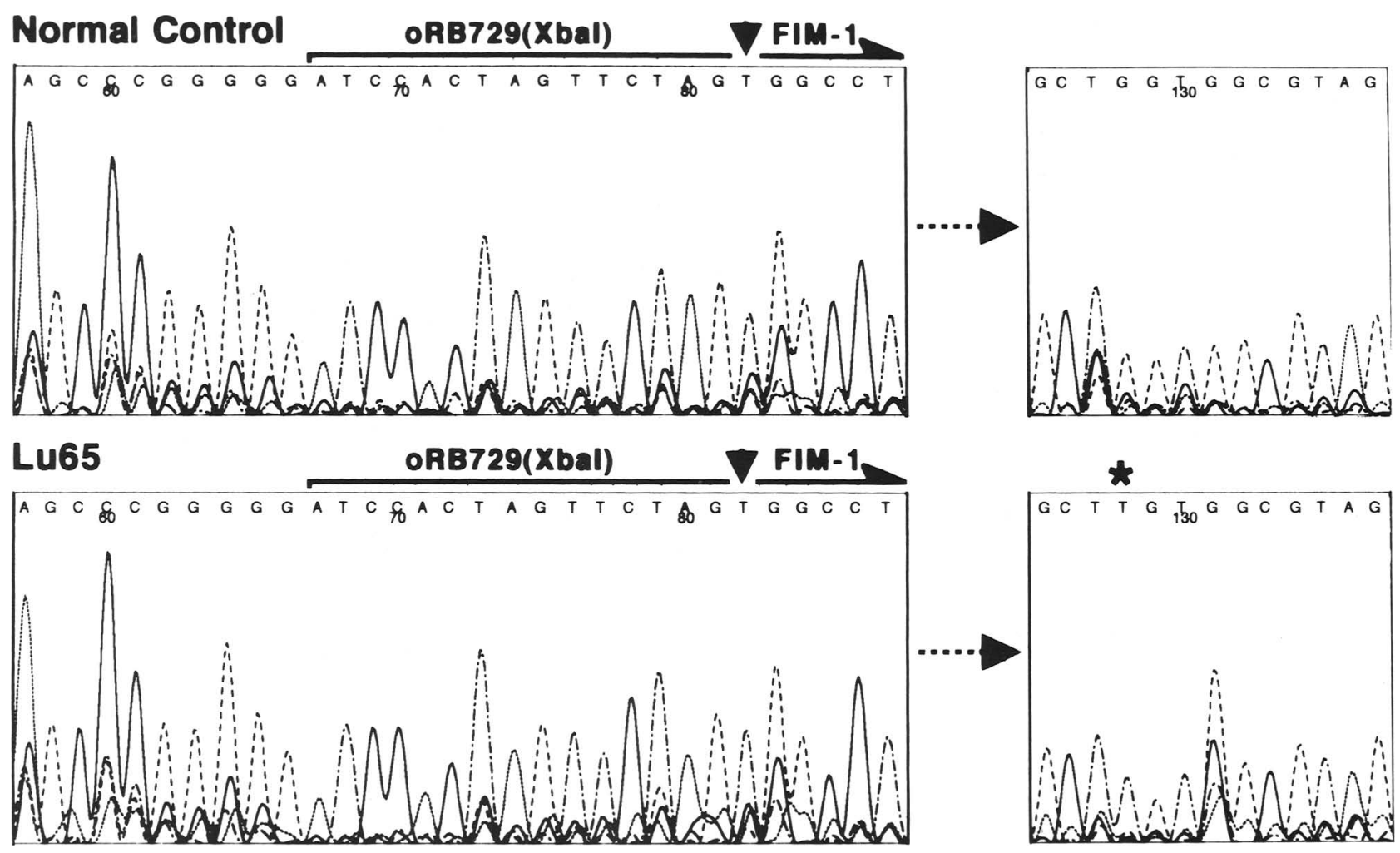

FIGURE 5 Direct sequencing of the second PCR products. The second PCR products with oRB399-FIM-2 using genomic DNA isolated from peripheral white blood cells of normal control or human lung cancer cell line of Lu65 as a template were subjected to direct DNA sequencing. Arrowheads show the complementary T to the overhanging A at the $3^{\prime}$ end of the PCR-amplified K-ras gene. The asterisk $\left({ }^{\star}\right)$ shows $\mathrm{T}$ substituting for $\mathrm{G}$ at codon 12 of the K-ras gene of Lu65. 
direct DNA sequencing using commercially available primers such as $\mathrm{T} 3, \mathrm{~T} 7$, or universal M13 primers. Because these PCR products have either the T3 or T7 promoter sequence, RNA could also be synthesized in vitro for various purposes. The final PCR product amplified by the third PCR had two different T-cassettes, cBT1 and CBT2, at both ends. Then, subcloning of the PCR-amplified DNA fragment could be accomplished by double digestions with two different endonucleases, which would make subcloning of the PCR product easy and efficient in the confined direction into $\mathrm{pB}$ luescript or other plasmids.

Although this method quickly supplies a template for sequencing or DNA fragments suitable for subcloning, it is necessary to confirm the sequence of PCR-amplified DNA fragment with Taq DNA polymerase, because the polymerase lacks the $3^{\prime} \rightarrow 5^{\prime}$ proofreading exonuclease activity and creates both single base substitution errors and frameshift errors during in vitro DNA synthesis. ${ }^{(16)}$ Using this method, we have successfully cloned DNA fragments of the genomic DNA of rat and human amidophosphoribosyltransferase (Honda et al., in prep.).

\section{ACKNOWLEDGMENTS}

This study was supported in part by a grant from Otsuka Pharmaceutical Factory Inc. for Otsuka Department of Clinical and Molecular Nutrition, School of Medicine, The University of Tokushima.

\section{REFERENCES}

1. Clark, J.M. 1988. Novel non-templated nucleotide addition reactions catalyzed by procaryotic and eucaryotic DNA polymerases. Nucleic Acids Res. 16: 9677-9686.

2. Lohff, C.J. and K.B. Cease. 1991. PCR using a thermostable polymerase with $3^{\prime}$ to 5 ' exonuclease activity generates blunt products suitable for direct cloning. $\mathrm{Nu}$ cleic Acids Res. 20: 144.

3. Scharf, S.J., G.T. Horn, and H.A. Erlich. 1986. Direct cloning and sequence analysis of enzymatically amplified genomic sequences. Science 233: 1076-1078.

4. Iwahana, H., T. Yamaoka, M. Mizutani, N. Mizusawa, S. Ii, K. Yoshimoto, and M. Itakura. 1993. Molecular cloning of rat amidophosphoribosyltransferase. J. Biol. Chem. 268: 7225-7237.

5. Marchuk, D., M. Drumm, A. Saulino, and F.S. Collins. 1991. Construction of T-vec- tors, a rapid and general system for direct cloning of unmodified PCR products. $\mathrm{Nu}$ cleic Acids Res. 19: 1154.

6. Holton, T.A. and M.W. Graham. 1991. A simple and efficient method for direct cloning of PCR products using ddT-tailed vectors. Nucleic Acids Res. 19: 1156.

7. Kovalic, D., J.-H. Kwak, and B. Weisblum. 1991. General method for direct cloning of DNA fragments generated by the polymerase chain reaction. Nucleic Acids Res. 19: 4560 .

8. Jones, D.H., K. Sakamoto, R.L. Vorce, and B.H. Howard. 1990. DNA mutagenesis and recombination. Nature 344: 793794.

9. Shuldiner, A.R., L.A. Scott, and J. Roth. 1990. PCR-induced (ligase-free) subcloning: A rapid reliable method to subclone polymerase chain reaction (PCR) products. Nucleic Acids Res. 18: 1920.

10. Aslanidis, C. and P.J. de Jong. 1990. Ligation-independent cloning of PCR products (LIC-PCR). Nucleic Acids Res. 18: 6069-6074.

11. Dietmaier, W., S. Fabry, and R. Schmitt. 1993. DISEC-TRISEC: di- and trinucleotide-sticky-end cloning of PCR amplified DNA. Nucleic Acids Res. 21: 3603-3604.

12. Iwahana, H., N. Mizusawa, S. Ii, K. Yoshimoto, and M. Itakura. An end-trimming method to amplify adjacent cDNA fragments by PCR. BioTechniques 16: 94-98.

13. Blin, N. and D.M. Stafford. 1976. A general method for isolation of high molecular weight DNA from eukaryotes. Nucleic Acids Res. 3: 2303-2308.

14. Taya, Y., K. Hosogai, S. Hirohashi, Y. Shimosato, R. Tsuchiya, N. Tsuchida, M. Fushimi, T. Sekiya, and S. Nishimura. 1984. A novel combination of K-ras and $m y c$ amplification accompanied by point mutational activation of K-ras in a human lung cancer. EMBO J. 3: 2943-2946.

15. Sambrook, J., E.F. Fritsch, and T. Maniatis. 1989. Isolation of DNA fragment from polyacrylamide gels. In Molecular cloning: A laboratory manual, 2nd ed., pp. 6.466.48. Cold Spring Harbor Laboratory, Cold Spring Harbor, New York.

16. Tindall, K.R. and T.A. Kunkel. 1988. Fidelity of DNA synthesis by the Thermus aquaticus DNA polymerase. Biochemistry 27: 6008-6013. 


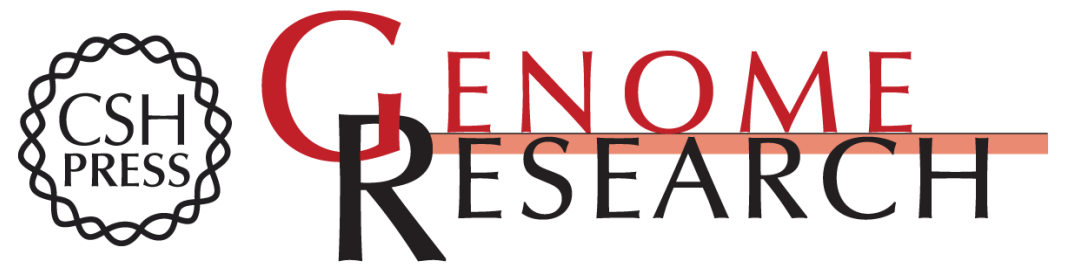

\section{T-cassette ligation: a method for direct sequencing and cloning of PCR-amplified DNA fragments.}

$\mathrm{H}$ Iwahana, K Yoshimoto, $\mathrm{T}$ Tsujisawa, et al.

Genome Res. 1994 3: 219-224

References This article cites 14 articles, 2 of which can be accessed free at: http://genome.cshlp.org/content/3/4/219.full.html\#ref-list-1

License

Email Alerting

Receive free email alerts when new articles cite this article - sign up in the box at the Service top right corner of the article or click here.

\section{Affordable, Accurate Sequencing.}

To subscribe to Genome Research go to: https://genome.cshlp.org/subscriptions 